\title{
Influence of the organic farming system on the composition of Bastardo Magarachskiy grape cultivar as a raw material for production of wines
}

\author{
Elena Stranishevskaya, Elena Ostroukhova, Irina Peskova, Svetlana Levchenko*, Elena Matveikina, and Nadezda Shadura
}

All-Russian National Research Institute of Viticulture and Winemaking "Magarach" of the RAS, Yalta, Russian Federation

\begin{abstract}
Studies on the effectiveness of applying the scheme for organic processing of grape cultivar Bastardo Magarachskiy in comparison with the traditional scheme of protection against the powdery mildew on the background of its strong progression were conducted. It was established, that the organic protection scheme is not inferior to the traditional processing scheme in its effectiveness and influence on the composition of grape berries. The biological effectiveness of the organic protection scheme in vineyards averaged $78.3 \%$. There is no significant difference in grapes obtained in the traditional and organic processing schemes by the mass of the bunch, the concentration of sugars and titratable acids in the berry. The use of biological products in foliar treatment had such beneficial effect on the formation of the phenolic complex of berries as the increase in supply of phenolic substances and growth of phenolic maturity. The use of organic protection scheme against powdery mildew led to a decrease in the concentration of pyruvic acid in juice by 2.5 times on average, compared with the traditional one, and an increase (in comparison with the traditional and control) by $1.4-1.6$ times of the concentration of $\alpha$-ketoglutaric acid. The studied treatment regimens did not affect the concentration of aldehydes.
\end{abstract}

\section{Introduction}

Modern concept of competitive viticulture and winemaking is based on the creation of products with a high level of safety for humans. It can be implemented subject to the cultivation of grapes in the system of organic farming and the use of scientifically based technologies for the production of wines, ensuring their environmental status [1-3].

Global trends in the development of production and food markets show that agricultural and food products, including grape and wine products, made without the use of pesticides, mineral fertilizers, growth regulators, artificial food additives, GMOs, etc. are highly demanded now. Ecologically clean or organic viticulture is based on the researches and development of safe methods of plant protection, including agricultural, physical and biological methods, on the ground of the use of parasite pathogenic fungi and bacteria, or using microbial drugs and biologically active substances, plant extracts, and phytosanitary monitoring in order to increase its productivity while maintaining the quality [4-6].

In recent years, Crimean vineyards previously used a traditional system of protective measures, started the increasing of united treatment schemes, including the combination of environmentally friendly drugs and permissible pesticides. Usage of such schemes helps to reduce the pesticidal load, improves greening and biologizing of grape production [7-9]. Application of chemical pesticides in this case is limited by two to three sprays per season, with five to six protective treatments by effective microbiological preparations [10-12]. The efficiency of combined processing schemes reaches $80 \%$.

Despite the fact that the area occupied with vineyards of organic farming system expands significantly, there is a lack of information on the influence of the farming system on the formation of quality characteristics of grapes, which determines the relevance of research in this direction.

This publication presents the results of a study of the effectiveness of biological preparations in protect-ing of vineyards from pests with the effect on the quality of berries as raw materials for the production of wines with ecological status.

\section{Materials and methods}

\subsection{Foliar biopreparations}

The following drugs were used in the work: in chemical protection scheme - Coside, Topaz, Talendo, Falcon, Collis, Dinali; in organic scheme - Extrasol, Tiovit Jet, Pseudobacterin, BioSleep BW (produced in Russian Federation). Extrasol is a microbiological fertilizer containing metabolic products of a strain of Bacillus

\footnotetext{
* Corresponding author: svelevchenko@rambler.ru
} 
subtilis; Tiovit Jet - a drug with a fungicidal, acaricidal and pesticidal effect, disrupts a number of vital processes of insect pest cells due to the release of sulfur; BioSleep BW is a biological insecticide that represents the blastospores of the Beauveria bassiana strain.

In our studies we evaluated the effectiveness of drugs and protective treatment regimens during the period of technical maturity of berries according to the "Guidelines for the registration testing of fungicides in agriculture" [13] and the "Guidelines for state testing of fungicides, antibiotics and protectants of seeds of agricultural crops" $[14,15]$; assessed the toxicity of biologically active substances against phytopathogenic fungi according to the method of M.N. Golyshina and N.S. Egorova [16-17].

\subsection{Grapes growing conditions and processing scheme}

The studies on Bastardo Magarachskiy grape cultivar (V. vinifera) were conducted in 2017- 2019 years. The cultivar was cultivated in traditional and organic farming systems, in the south coastal region of Crimea (Livadia branch of GUP RK PJSC Massandra). The culture is uncovered. Planting scheme is $3.0 \times 1.5 \mathrm{~m}$. The total area of vineyard plots used in the research is three hectares.

The plant protection system adopted on the farm (SPH) provides 8 treatments with chemicals of different action: Coside, 0.7 1/ha 2000 ( $2 \mathrm{~kg} / \mathrm{ha}) \rightarrow$ Topaz, emulsion concentrate $(\mathrm{CE})(0.4 \mathrm{l} / \mathrm{ha}) \rightarrow$ Talendo, CE $(0.2$ l/ha $) \rightarrow$ Dinali, (0.7 l/ha) $\rightarrow$ Talendo, CE (0.2 1/ha) $\rightarrow$ Falcon, CE $(0.4$ 1/ha $) \rightarrow$ Collis, suspension concentrate $(\mathrm{CS})(0.5$ 10/ha $) \rightarrow$ Dynali, dispersion concentrate (DC), (0.7 1/ha).

The experimental organic farming system included the processing of biological drugs: Extrasol, (4 1/ha) $\rightarrow$ Extrasol (4 1/ha) + BioSleep BW (3 1/ha) $\rightarrow$ Tiovit Jet, water-soluble granules (VDG) - (6 kg/ha) $\rightarrow$ Tiovit Jet, VDG (6 kg/ha) $\rightarrow$ Extrasol (4 1/ha) + BioSleep BW (3 $1 /$ ha $) \rightarrow$ Extrasol + Tiovit Jet, VDG (4 1/ha $+6 \mathrm{~kg} / \mathrm{ha})$ $\rightarrow$ Psevdobacterin- 2 (4 1/ha) + BioSleep BW (3 1/ha) $\rightarrow$ Extra Sol (4 1/ha) + BioSleep BW (3 1/ha) $\rightarrow$ Extrasol (4 1/ha).

The treatments were carried out in the following phases of vegetation: growth of shoots and inflorescences (5-7 leaves); growth of shoots and inflorescences (10-12 leaves); before flowering; after flowering; the beginning of the growth and formation of berries; berry growth and formation; the beginning of berries ripening; berries ripening; with an organic protection scheme -2 weeks before cleaning. Control the system without processing.

\subsection{Sample preparation, determining the parameters of grape productivity, chemical analysis of grapes}

The productivity and quality of grapes from 20 bushes (4 replicates of 5 plants) in all research options was evaluated. Aerobiological surveys, assessment of the crop and its quality was carried out according to the "Methodological and analytical support for organizing and conducting research on grape production technology" [18]. A combined sample from 5 bushes of each replication of experienced schemes was taken to analyze the chemical composition of berry. Sample's weight was about $1000 \mathrm{~g}$.

\subsubsection{Sample preparation and chemical analysis of grapes}

To determine the content of sugars and titrated acids, $300-350 \mathrm{~g}$ of the berries of each sample were crushed in a turbo blender (Moulinex-LM600E, France) during 2 min. The mixture was centrifuged at $5000 \mathrm{rpm}$ (Sigma 4K10 Braun, Germany) for $15 \mathrm{~min}$ at room indoor temperature to get a cleansed juice. Then the juice was filtered through $0.45 \mu \mathrm{m}$ pore size membrane filters and incubated for analysis at $20^{\circ} \mathrm{C}$. Total sugars were determined by using areometric method, the titratable acids - by titrimetric method recounted for tartaric acid.

The concentration of phenolic substances was determined using the Folin-Ciocalteu reagent, phenolic maturity - Glories method [19, 20]. The study of the polyphenol oxidase (PPfO) activity and the content of $\mathrm{SO}_{2}$-binding components were carried out in freshly squeezed juice obtained by manual pressing of the whole berries. Polyphenol oxidase activity was evaluated by the rate of formation of blue-violet color of oxidized diethyl paraphenylenediamine sulfate. The concentration of keto acids was determined by their ability to react with 2,4dinitrophenylhydrazine with the formation of substances colored intensely in orange or red, aldehydes - by the titrimetric method [19].

\subsection{Statistical analysis of the data}

All chemical analyses were performed in triplicate. The data were mathematically processed with the help of statistical software package SPSS Statistics 17.0. Arithmetic mean value, variance of a single result and standard deviation (SD) were determined.

\section{Results and discussion}

The data of Table 1 show that the progression of the disease on grape bunches was $32.7 \%$ in the control variant. Chemical protection scheme and organic system decreased the value of parameter by 4.5 and $7.1 \%$ respectively.

The biological effectiveness of the organic protection scheme was $9 \%$ lower than the efficiency of chemical protection scheme and averaged $78.3 \%$. Despite the fact that the use of chemical protection scheme led to a $14 \%$ increase, and the organic scheme to a $7 \%$ reduction in the weight of the bunch relative to the control variant, these differences were not statistically significant. This statement is also true for parameters that reflect the progression of the disease and the biological effectiveness of the treatments. 
Table 1. The effectiveness of the organic protection scheme against powdery mildew and on the productivity and yield quality*.

\begin{tabular}{|c|c|c|c|c|c|c|c|}
\hline \multirow{2}{*}{$\begin{array}{c}\text { Treatment } \\
\text { variants }\end{array}$} & \multirow{2}{*}{$\begin{array}{c}\text { Disease } \\
\text { development } \\
\text { of the on } \\
\text { bunches, \% }\end{array}$} & \multirow{2}{*}{$\begin{array}{c}\text { Biological } \\
\text { efficiency, } \\
\%\end{array}$} & \multirow{2}{*}{$\begin{array}{l}\text { Bunch } \\
\text { weight, } \\
\text { g }\end{array}$} & \multirow{2}{*}{$\begin{array}{l}\text { Bunch weight } \\
\text { change } \\
\text { according to } \\
\text { chemical } \\
\text { protection } \\
\text { scheme, } \%\end{array}$} & \multicolumn{2}{|c|}{ Concentration } & \multirow{2}{*}{ pH } \\
\hline & & & & & $\begin{array}{c}\text { sugars, } \\
{ }^{\circ} \mathrm{Br} \text {. }\end{array}$ & $\begin{array}{c}\text { titratable } \\
\text { acids, } \mathrm{g} \mathrm{L}^{-1}\end{array}$ & \\
\hline Control & $32.7 \pm 2,1$ & - & $142.7 \pm 14.1$ & -12.5 & $19.1 \pm 0.9$ & $6.6 \pm 0.4$ & $3.52 \pm 0.04$ \\
\hline $\begin{array}{l}\text { Chemical } \\
\text { protection } \\
\text { scheme (ChPS) }\end{array}$ & $4.5 \pm 1,2$ & $86.2 \pm 2,4$ & $163.0 \pm 14.6$ & & $17.2 \pm 1.1$ & $7.1 \pm 0.6$ & $3.49 \pm 0.06$ \\
\hline $\begin{array}{l}\text { Organic } \\
\text { protection } \\
\text { scheme (OPS) }\end{array}$ & $7.1 \pm 1,7$ & $78.3 \pm 2,9$ & $133.3 \pm 12.3$ & -18.2 & $18.8 \pm 1.4$ & $6.7 \pm 0.4$ & $3.45 \pm 0.06$ \\
\hline
\end{tabular}

We assessed the influence of chemical protection scheme and the organic protection scheme of grape plants on the chemical composition of grape berries. The variation in treatment regimens did not significantly affect the concentration of sugars and titratable acids in the berry (Table 1). A technologically important parameter of redberry grape varieties as raw materials for wine production is their phenolic maturity and the technological supply of phenolic substances in berry. The use of an organic treatment scheme contributed to an increase in the technological stock of phenolic substances by $22 \%$ in comparison with the control version and by $4 \%$ compared to the chemical protection scheme (Figure 1). On average, the supply of phenolic substances in grape berry, obtained in the process of organic farming system, was $2328 \pm 347 \mathrm{mg} \mathrm{L}^{-1}$, that favorably effects on the quality of the resulting wines. Besides, the use of organic processing scheme led to an increase not only in the potential amount of anthocyanins in berry by $11-20 \%$ on average, but also in their easily extractive forms by $3-11 \%$. The share of easily extractable anthocyanins $\left(\mathrm{ApH}_{3,2}\right)$ in the grapes of the experimental and control lots varied from 55 to $61 \%$, and the proportion of seed tannins did not exceed $10 \%$. According to previous studies [21, 22], such values of parameters show that grapes have reached phenolic maturity.

The treatment by organic protection scheme compared to chemical protection scheme and control led to an increase in the PPfO activity by 1.3-3.3 times (Figure 1). As a result, the parameter values exceeded the values recommended by us in the production of red wines $(\leq 0.09$ c.u $)[23,24]$.
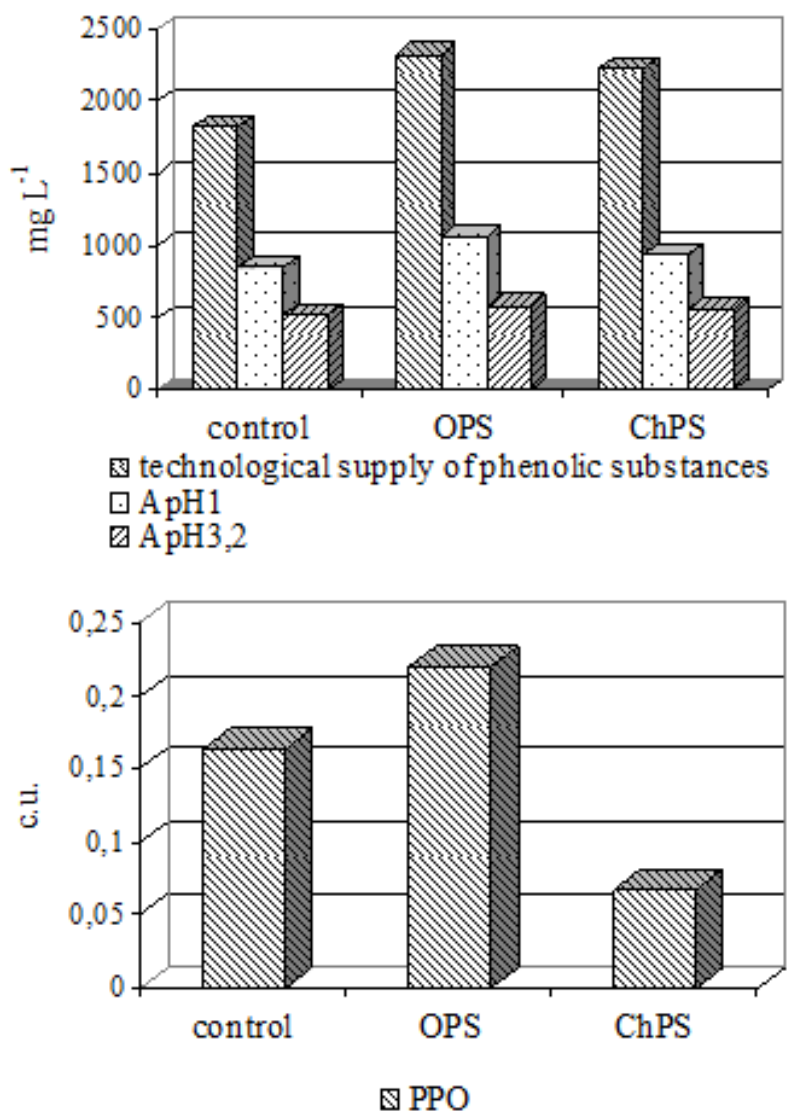

Fig. 1. Phenolic complex and PPfO activity of grape cultivated in traditional and organic farming systems.

In recent years, the studies noticed an increase in the response of PPfO activity in plants to biotic stress, the action of pathogenic organisms, and the activity of photosynthesis $[25,26]$. In this connection, the parameter can be considered as one of the criteria for assessing the effectiveness of the protection system used $[25,26]$.

Reduction of sulfur dioxide doses in every stage of wine production is one of the tasks of organic winemaking. Sulfur dioxide is used in winemaking due to the antiseptic, anti-oxidase and anti-oxidative effects exhibited in free forms: molecular, bisulphite and sulfite 
[27]. The concentration level of free forms of sulfur dioxide in the grape-wine system depends on the $\mathrm{pH}$, temperature, amount and composition of the microflora of grapes, the activity of grape oxidases, the content of $\mathrm{SO}_{2}$-binding components in grape must and wine, etc. $[28,29]$. The use of organic protection scheme against powdery mildew decreased a concentration of pyruvic acid, by 2.5 times on average, in comparison with chemical protection scheme, and increased the concentration of $\alpha$-ketoglutaric acid by $1.4-1.6$ times in comparison with chemical protection scheme and control (Figure 2). Studied treatment regimens did not affect the concentration of aldehydes (Figure 2). The total $\mathrm{SO}_{2-}$ binding ability of grapes in organic protection scheme decreased by 1.3 times on average relative to the control and increased by 1.4 times on average relative to the organic protection scheme.

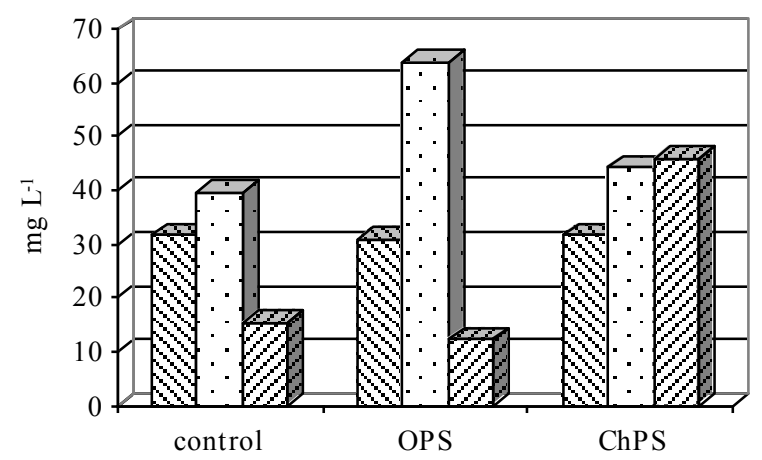

$\square$ aldehydes $\square$ ketoglutaric acid $\square$ pyruvic acid

Fig. 2. Content of sulfur dioxide binders of grapes cultivated in traditional and organic farming systems.

\section{Conclusion}

The greening of agriculture, the stimulation of the plant's own immunity system are the relevant direc-tions for reducing the pesticide loading in the biosphere. A comparison of the influence of organic and chemical protection schemes on the actions against the powdery mildew showed the absence of a significant difference of the yield, weight of the bunch, concentration of sugars and titratable acids in berries. The use of organic protection scheme had a beneficial effect on the formation of the phenolic complex of berries, manifested in increasing of the phenolic and anthocyanin substances supply and phenolic maturity. Variation in plant protection schemes effects the concentration of sulfur dioxide-binding components. The use of the organic protection scheme was accompanied by a decrease in the concentration of pyruvic acid (by 2.5 times on average) and an increase in the concentration of $\alpha$ ketoglutaric acid (by 1.4 times on average). The total SO2-binding ability of the juice decreased by 1.3 times on average compared to the control and was 1.4 times higher in comparison with chemical protection scheme.

In general, the organic protection scheme tested on Bastardo Magarachskiy grape cultivar against the powdery mildew on the background of its strong progression is not inferior in its effectiveness and influence on grape berries compared to the traditional chemical protection scheme.

\section{References}

[1] D. Madge, Organic viticulture: an Australian manual, Department of Primary Industries, Victoria (2005).

[2] D Dangour, K. Lock, A. Hayter, A. Aikenhead, E. Allen, R. Uauy, The American Journal of Clinical Nutrition, 92, 1, 203-210 (2010).

[3] A.I. Guskov, Management of economic system. Sci. el. J. [Electronic resource]. Available at: http://uecs.ru/marketing/item/2614-2013-12-1210-19-08.

[4] H. Willer, J. Lernoud, Organic Viticulture Worldwide 2015, Research Institute of Organic Agriculture (FiBL), Frick, Switzerland (2015).

[5] H. Willer, J. Lernoud, L. Kemper, The World of Organic Agriculture 2019: Summary, FiBL \& IFOAM [Electronic resource]. Available at: https://shop.fibl.org/CHen/mwdownloads/downlo ad/link/id/1202/?ref=1.

[6] J. Lernoud, H. Willer, Current Statistics on Organic Agriculture Worldwide: Area, Operators, and Market, FiBL \& IFOAM [Electronic resource]. Available at: https://shop.fibl.org/CHen/mwdownloads/downlo ad/link/id/1202/?ref=1.

[7] E. Stranishevskaya, Ya. Volkov, E. Matveikina, N. Shadura, Magarach, Viticulture and Winemaking, 20, 4, 106, 70-72 (2018).

[8] Ya. Volkov, T. Parkhomenko, A. Parkhomenko, E. Stranishevskaya, E. Matveykina, V. Volodin, Scientific works of the state scientific institution of the North-Caucasian zone research institute of horticulture and viticulture, Krasnodar, 11, 137144 (2016).

[9] Ya. Volkov, E. Matveykina, E. Stranishevskaya, A. Kolosova, Russian grapes, 5, 123-133 (2017).

[10] P. Nedov, Problematic issues of protecting grapes from harmful organisms: materials of the AllUnion Scientific and Practical Conference, Institute of Viticulture and Winemaking "Magarach", Yalta (1990).

[11] T.A. Ryabchinskaya, G.L. Harchenko, Plant Protection, 7, 10-12 (2008).

[12] V.S. Petrov, T.A. Nudga, T.P. Pavlyukova, A.I. Talash, E.G. Yurchenko, Winemaking and Viticulture, 5, 10-12 (2012).

[12] Guidelines for registration testing of fungicides in agriculture, SPb (2009).

[13] K.V. Novozhilova, Guidelines for state testing of fungicides, antibiotics and seed dressers of agricultural crops, M.: Kolos (1985).

[14] B.A. Dospekhov, The methodology of field experience, M.: Kolos (1985).

[15] N.M. Golyshin, Fungicides in agriculture, M.: Kolos (1970). 
[16] N.S. Egorov, The basics of the doctrine of antibiotics, Textbook for university students, M.: Higher School (1969).

[17] K.A. Serpukhovitina, Methodological and analytical support for the organization and conduct of research on grape production technology, Krasnodar: GNU SKZNIISiV (2010).

[18] V.G. Gerzhikova, Methods of technochemical control in winemaking, Simferopol: Tavrida (2009).

[19] K.A. Joutei, D. Bouya, C. Saucier, Y. Glories, Influence de l'éthylène sur les maturités phénolique et cellulaire des raisins au cours de la vinification. Cah. Agric, 15, 371-374 (2006).

[20] E. Ostroukhova, S. Levchenko, V. Likhovskoi, V. Volynkin, I. Peskova, I. Vasylyk, Acta Hortic., 1259, 105-114 (2019). DOI: 10.17660/ActaHortic.2019.1259.18.

[21] S. Levchenko, E. Ostroukhova, I. Peskova, P. Probeigolova, International Symposium on Horticulture: Priorities and Emerging Trends, India, Bengaluru (5-8 September 2017).

[22] E. Ostroukhova, I. Peskova, P. Probeigolova, N. Lutkova, Magarach, Viticulture and Winemaking, 2, 31-34 (2018).

[23] E. Ostroukhova, I. Peskova, P. Probeigolova, N. Lutkova, Problems of development of the agroindustrial complex of the region, 3, 35, 185-193 (2018).

[24] T. Boeckx, A. Winters, K.J. Webb, A.H. Kingston-Smith, Detection of Potential Chloroplastic Substrates for Polyphenol Oxidase Suggests a Role in Undamaged Leaves Front. Plant Sci., 12, $2017 . \quad$ DOI: 10.3389/fpls.2017.00237.

[25] T. Boeckx, A.L Winters, K.J. Webb, A.H. Kingston-Smith, Polyphenol oxidase in leaves: is there any significance to the chloroplastic localization?, J Exp Bot., 66, 12, 3571-3579 (2015). DOI: 10.1093/jxb/erv141. Epub 2015 Apr $4]$.

[26] R.B. Boulton, V.L. Singleton, L.F. Bisson, R.E. Kunkee, Principles and practi ces of winemaking, New York: Chapman \& Hall (1996).

[27] T.C. Somers, L.G. Wescombe, Aust Grapegrow Winemak, 220, 68-74 (1982).

[28] C. Butzke, Use of $\mathrm{SO}_{2}$ in High-pH Wines, Purdue Extension [Electronic resource]. Available at: https://www.extension.purdue.edu/extmedia/ FS/FS-52-W.pdf. 